УДК 504.5:628.4.047:638.17 (477.41/42)

DOI: 10.37128/2707-5826-2021-4-15

\title{
ІНТЕНСИВНІСТЬ НАКОПИЧЕННЯ
} ЦЕЗІЮ-137 У ПРОДУКЦІЇ БДЖІЛЬНИЦТВА ЗА МІНЕРАЛЬНОГО УДОБРЕННЯ НА РАДІОАКТИВНОЗАБРУДНЕНИХ ГРУНТАХ

\author{
С.Ф. РАЗАНОВ, доктор с.-г. наук, \\ професор, \\ Вінницький національний \\ аграрний університет \\ М.Ф. КОМИНАР, аспірант, \\ Інститут агроекологіï $i$ \\ природокористування НААН
}

Якість та безпека продукиії рослинництва, зокрема, нектару $і$ квіткового пилку, які є сировиною виробництва продукиї бджільництва, залежить від стану трунтів, його складу, вмісту гумусу, мінеральних речовин, рівня зволоження та рівня забруднення токсикантами.

Особливої уваги в останні декілька десятирічь набуває проблема забруднення трунтів різними токсикантами, серед яких високу небезпеку представляють радіонукліди, щчо потрапили в навколишнє середовище внаслідок аварії на Чорнобильській АЕС, яка призвела до забруднення иезієм-137 вище $37 \kappa Б \kappa / \mathrm{m}^{2}$ 461,7 тис. га сільськогосподарських угідь, з них орних земель - 345,9 тис. га.

Найбільші площзі угідь, забруднених цеезієм-137, поширені в Житомирській (156 тис. га), Черкаській (76 тис. га), Рівненській (52 тис. га), Чернігівській (52 тис. га), Віннищькій (50 тис. га), Київській (34 тис. га.) областях. Зокрема, у Черкаській і Вінницькій областях одержання сільськогосподарської продукиії, забрудненої вище допустимих рівнів, протягом останніх років не виявлено. До території, де існує постійна небезпека забруднення радіонуклідами трунтів та продукції рослинництва, необхідно віднести насамперед північні райони Полісся, які найбільше постраждали від аварії на Чорнобильській АЕС.

За результатами проведених досліджень виявлено, щуо питома активність цезію-137 у меді та бджолиному обніжжі, одержаних з нектару $і$ квіткового пилку озимого ріпаку та сонямнику на трунтах із вмістом даного радіонукліду від 2305 Бк/кг до 2407 Бк/кг в умовах півночі Житомирщини, не перевищує ДР-2006. Водночас за удобрення трунтів мінеральними добривами спостерігається підвищення питомої активності иеезію-137, його коефіиієнтів небезпеки і накопичення у меді та бджолиному обніжжі при використанні аміачної селітри, тоді як за використання суперфосфату простого, калію хлористого, суміші NPK добрив відмічено зниження даних показників. У всіх варіантах за удобрення трунтів мінеральними добривами у меді та бджслиному обніжжі, виробленого бджолами з нектару $і$ квіткового пилку ріпаку озимого і соняшнику, перевищень ДР-2006 не спостерігалось. Найвищу питому активність изезію-137, його коефіиієнтів небезпеки $і$ накопичення у меді та бджолиному обніжжі, вироблених бджолами з нектару $і$ пилку з озимого ріпаку та соняшнику, було виявлено у варіанті за удобрення трунтів аміачною селітрою. Найнижчий вплив мінеральних добрив на інтенсивність транслокації цеезію-137 у ланцюгу трунт - рослина - нектар - мед квітковий пилок - бджолине обніжжя виявлено за використання калію хлористого. Так, за удобрення трунтів калієм хлористим у меді та бджолиному обніжжі, виробленими бджолами з нектару $і$ пилку озимого ріпаку питома активність цезію-137 була нижчою порівняно з аміачною селітрою на 44,9\% i 43,4\%, суперфосфатом простим - на 18,8\% і 18,0 \% та сумішшю NPK добрив - на 12,8\% i 24,0\%. У меді та бджолиному обніжжі, виробленими бджслами з нектару і пилку сонямнику, за удобрення трунтів калієм хлористим питома активність иезію-137 була нижча порівняно за використання аміачної селітри на 50,6\% і 53,1\%, на 27,1\% і 32,6\% та 7,2\% і 67,7\% відповідно. 
Ключові слова: ичезій-137, нектар, квітковий пилок, мед, бджолине обніжжя, питома активність, озимий ріпак, сонямник, коефіцієнт накопичення, коефіцієнт небезпеки.

Табл. 5. Рис. 1. Літ. 17.

Постановка проблеми. Продукція бджільництва (мед, бджолине обніжжя) знайшла своє широке застосування серед населення. Вона характеризується високим вмістом біологічно активних речовин. Зокрема, у меді міститься висока концентрація простих цукрів, вітамінів, мінеральних речовин тощо, тоді як бджолине обніжжя характеризується високим вмістом амінокислот, мінеральних речовин, вітамінів та ін. Основу складових речовин меду формують цукри. Вони входять до групи вуглеводів, яких у складі меду понад 40 видів. Харчова та лікувальна цінність меду пояснюється передусім значним вмістом простих цукрів - фруктози і глюкози, суміш яких називають інвертним цукром. Високоякісні сорти меду містять до 75\% простих цукрів (глюкози, як правило, близько $35 \%$, фруктози - 40\%). Співвідношення їх визначає фізичні якості меду: під час збільшення вмісту глюкози підвищується його кристалізаційна здатність, а під час збільшення вмісту фруктози мед стає солодшим на смак і більш гігроскопічним. За даними Української дослідної станції бджільництва, різні сорти меду містять у середньому 68,5-74,1\% інвертного цукру. Вміст азотистих сполук у меді становить у середньому $0,4 \%$, а мінеральних речовин - 0,17\% [3].

Пилок містить багато незамінних амінокислот у складі білків та у вільному стані. Зібраний з різних рослин пилок повністю забезпечує бджіл незамінними амінокислотами, до яких належать аргінін, валін, гістидин, ізолейцин, лейцин, лізин, метіонін, треонін, триптофан, фенілаланін. Сорти пилку різняться за вмістом білка й амінокислот. Вміст жиру в пилку різних рослин неоднаковий, $\%$ : персика $-2,7$, сливи $-3,1$, конюшини білої - 3,2, верби $-4,1$. Найбільший вміст жиру - 14,4 \% спостерігається у пилку кульбаби. Жири та жироподібні речовини бджолина сім'я використовує лише з пилку $[12,15]$.

Вміст цукрів у пилку різних рослин також різний, причому в обніжжі їх більше, ніж у пилку на квітках до збирання бджолами. Це пояснюється тим, що для зліплювання його в грудочки бджоли використовують нектар або мед із зобиків. Така обробка значно підвищує цукристість продукції - від 7,5 до $41,2 \%$, особливо коли пилкова маса погано формується в обніжжя. Співвідношення різних цукрів у процесі обробки i дозрівання продукції змінюється, оскільки складні цукри гідролізуються, в результаті чого полі- i олігосахариди перетворюються на прості, які легко засвоюються організмом [15]. Завдяки своїм цілющим та високопоживним властивостям продукція бджільництва широко використовується в харчуванні населення та медичний практиці, попит на яку постійно зростає $[4,17]$. Поряд 3 високим попитом на продукцію бджільництва зростають і вимоги до їі якості та безпеки [9]. Внаслідок забруднення нектаро-пилконосних угідь радіонуклідами, особливо на територіях північного Полісся, виявлено певне накопичення 
радіонуклідів у продукції бджільництва, що суттєво вплинуло на ії якість і безпеку $[1,2,5,11]$. Встановлено також, що інтенсивність забруднення меду і квіткового пилку залежить від рівня забруднення територій та від ботанічного походження нектаро-пилконосів $[4,8,13,16]$.

Аналіз останніх досліджень та публікацій. Радіонукліди, зокрема цезій137, у грунтах знаходяться у рухомому стані, тому переміщуються у певні його прошарки та рослинність. Швидкість такого переміщення радіонуклідів у грунті залежить від його властивостей, вмісту мінеральних та органічних речовин. Виявлено, що міграція цезію-137 на мінеральних дерново-підзолистих грунтах у десятки разів нижча, ніж на торф'яних і торф'яно-болотних грунтах. Це характерно грунтам екологічної зони Полісся. До складу грунтів цієї зони входить не більше 1,0\% глини, 0,8-1,2\% гумусу, 3-5\% мулистої фракції, що спричинює високу міграцію радіонуклідів. Цезій-137 у цих грунтах знаходиться у дернині у швидкорухомій формі та доволі інтенсивно мігрує у рослинність та iї продукцію. Доведено, що найвищими сорбційними властивостями володіють чорноземи. В дерново-опідзоленому та супіщаному грунтах закріплення радіонуклідів нижче, порівняно з чорноземами. Велику роль у затриманні радіонуклідів у грунтах відіграє механічний склад грунтів. Важкі за механічним складом грунти закріплюють інтенсивніше радіонукліди, особливо цезій-137, порівняно з легкими [10].

Серед низки радіоактивних елементів найбільшу небезпеку представляє цезій-137, який $\epsilon$ аналогом калію та має період розпаду 60 років. У грунтах цезій-137 зберігає досить високу міграцію, що створює активну трансформацію його у рослинність та іï продукцію. Переміщення даного радіонукліду в грунтовому середовищі та в ланцюгу грунт-рослина залежить від цілого ряду факторів, які в тій чи іншій мірі впливають на інтенсивність нагромадження його рослинністю. Основними із них $є$ тип грунтів, рівень їх зволоження, механічний склад, $\mathrm{pH}-г$ рунтового розчину, ботанічне походження рослин, система обробітку грунтів та їх удобрення $[6,10]$.

Доведено, що за високого рівня в грунтах води спостерігається вища інтенсивність переміщення цезію-137 в рослинність. На чорноземах зазвичай переміщення цезію-137 у рослинність нижча порівняно з іншими грунтами, особливо 3 торф'яними. Високий рівень $\mathrm{pH}$ грунтів сприяє підсиленню переміщення цезію-137 порівняно 3 близьким до нейтрального показника. Переорювання грунтів також змінює інтенсивність переміщення цезію-137 в ланцюгу грунт-рослина внаслідок зміни концентрації даного радіонукліду в зоні кореневої системи. Надходження таких елементів, як фосфор, у грунти підсилює їх сорбційні властивості, а кадмію - знижує засвоєння цезію-137 кореневою системою, внаслідок чого знижується міграційна спроможність даного радіонукліду у рослинність [6].

Відомо, що мінеральні добрива помітно впливають на трансформацію радіонуклідів з грунтів у рослинність. Так, надходження цезію-137 в рослини та нагромадження його в урожаї значно залежить від вмісту у грунтах калію. Тому 
удобрення грунтів калійними добривами є одним з головних заходів зменшення вмісту цезію-137 в продукції рослинництва, який дає можливість знизити його питому активність до 3 разів, а в окремих випадках і до 6 разів. Встановлено також помітне зниження цезію-137 рослинами як за листового, так i за кореневого підживлення рослин калійними добривами. Так, рівень калійного живлення рослин істотно впливає на нагромадження цезію-137 у надземних органах при надходженні його через листя. При внесенні калійних добрив у грунт і при обприскуванні ними листя вміст цезію-137 у вегетативних органах рослин помітно знижується. Рослини-калієфіли, як правило, поглинають цезій-137 у більших кількостях, ніж звичайні види $[6,10]$.

Солі фосфорних кислот можуть утворювати зі стронцієм нерозчинні сполуки. Тому при внесенні у грунт фосфорних добрив може значно знизитись перехід стронцію-90 з грунту у рослини. Найефективнішими з них є добрива, які містять фосфати кальцію та калію. Внесення у грунт тризаміщеного фосфату калію у декілька разів зменшує вміст у рослинах як стронцію-90, так i цезію-137. Фосфати амонію, натрію, магнію впливають здебільшого тільки на вміст стронцію-90.

На забруднених радіоактивними речовинами грунтах слід обережно підходити до використання азотних добрив. При їх внесенні збільшується нагромадження в рослинах цезію-137, а іноді й стронцію-90. Загальне збільшення норми повного мінерального добрива також призводить до нагромадження у рослинах цезію-137. Тому найбільш толерантним співвідношенням азотних, калійних і фосфорних добрив є показник 1:2:1,5.

Внесення в грунт органічних добрив може істотно зменшити надходження в рослини радіоактивних речовин. Особливо ефективне внесення гною, перегною, низинного торфу на грунтах легкого механічного складу. Органічні речовини добрив запобігають не тільки надходженню в рослини стронцію-90 та цезію-137, а й інших радіонуклідів [6, 10].

Помітно знижується накопичення цезію-137 і стронцію-90 при спільному внесенні в дерново-підзолисті грунти органічних і вапняних добрив. Цей захід $\epsilon$ одним з найістотніших серед агрономічних заходів, спрямованих на зменшення надходження радіонуклідів 3 грунту та збільшення врожаю сільськогосподарських культур. На даний час спостерігається тенденція повернення тимчасово вилучених 3 використання внаслідок забруднення радіонуклідами під час аварії на Чорнобильській АЕC грунтів сільськогосподарського призначення у виробництво, у зв'язку з чим виникає потреба у вивченні інтенсивності забруднення продуктів переробки бджолиного нектару і квіткового пилку, вироблених із сільськогосподарських нектаропилконосів за удобрення радіоактивно забруднених грунтів.

Постановка завдання. Використання добрив на забруднених радіоактивними речовинами грунтах $є$ одним 3 головних заходів зменшення надходження радіонуклідів у сільськогосподарські рослини, однак, у продукції переробки бджолами нектару i квіткового пилку вивчено недостатньо. 
Матеріали і методи досліджень. Дослідження з вивчення інтенсивності накопичення цезію-137 у меді і бджолиному обніжжі, вироблених бджолами 3 нектару i квіткового пилку основних сільськогосподарських культур за мінерального удобрення грунтів, проводили в умовах північного Полісся в межах Народицької селищної територіальної громади Житомирської області.

Характерними ознаками даного регіону є низький рельєф 3 широкими заболоченими річковими долинами, з високим рівнем грунтових вод. Грунтовий покрив району досліджень характеризується переважно дерново-підзолистими та перезволоженими оглеєними грунтами. Незважаючи на високий рівень грунтових вод, на окремих територіях спостерігається недостатня вологозабезпеченість через наявність піщаних і супіщаних грунтів. Найвища перезволоженість місцевості (заболочення) спостерігається в північній та північно-західній частині регіону.

Вивчення впливу мінерального удобрення грунтів проводили згідно програми досліджень (табл. 1).

Табличя 1

Програма досліджень

\begin{tabular}{|c|c|c|c|}
\hline $\begin{array}{l}\text { Нектаро- } \\
\text { пилконоси }\end{array}$ & $\begin{array}{c}\text { Варіанти досліджень за } \\
\text { удобрення грунтів }\end{array}$ & $\begin{array}{c}\text { Продукція } \\
\text { бджільництва }\end{array}$ & $\begin{array}{c}\text { Показники визначення } \\
\text { впливу мінерального } \\
\text { удобрення грунтів на } \\
\text { накопичення цезію-137 }\end{array}$ \\
\hline $\begin{array}{l}\text { Ріпак } \\
\text { озимий }\end{array}$ & $\begin{array}{l}\text { 1. Без удобрення } \\
\text { 2. Аміачна селітра, } 80 \text { кг/га } \\
\text { 3. Суперфосфат простий, } 60 \\
\text { кг/га } \\
\text { 4. Калій хлористий, } 90 \text { кг/га } \\
\text { 5. Суміш } \mathrm{N}_{80} \mathrm{P}_{60} \mathrm{~K}_{90}\end{array}$ & $\begin{array}{c}\text { Мед. } \\
\text { Бджолине } \\
\text { обніжжя }\end{array}$ & 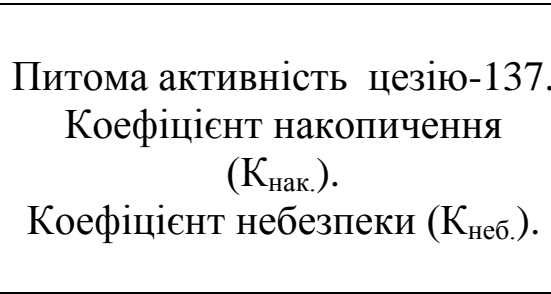 \\
\hline Соняшник & $\begin{array}{l}\text { 1. Без удобрення } \\
\text { 2. Аміачна селітра, } 45 \text { кг/га } \\
\text { 3. Суперфосфат простий, } 45 \\
\text { кг/га } \\
\text { 4. Калій хлористий, } 45 \text { кг/га } \\
\text { 5. Суміш } \mathrm{N}_{45} \mathrm{P}_{45} \mathrm{~K}_{45}\end{array}$ & $\begin{array}{c}\text { Мед. } \\
\text { Бджолине } \\
\text { обніжжя }\end{array}$ & $\begin{array}{c}\text { Питома активність цезію- } \\
137 . \\
\text { Коефіцієнт накопичення } \\
\left(\mathrm{K}_{\text {нак.). }}\right. \\
\text { Коефіцієнт небезпеки (К } \text { Кеб.). }\end{array}$ \\
\hline
\end{tabular}

Джерело: сформовано на основі власних досліджень

Грунти для радіологічних досліджень відбирали методом конверту 3 кожного поля, на якому вирощували сільськогосподарські медоноси (ріпак озимий, соняшник). Загальна схема відбору проб грунтів включала: відбір грунту у п'яти точках на глибині їх переорювання 3 видаленням залишків вегетативної маси, формування середньої проби та відбір способом точкових проб представницької проби масою 500 грам з кожного поля, пакування та маркування зразків. Мед для досліджень відбирали алюмінієвим пробовідбірником методом точкових проб 3 кожної відкачаної партії меду, виробленого бджолами із соняшнику та ріпаку озимого. Ботанічне походження меду визначали за пилковим аналізом. 3 кожної партії меду було відібрано по 
500 грам для лабораторних аналізів. Бджолине обніжжя відбирали від бджолиних сімей пиловловлювачем загальновідомим способом, описаним В.П. Поліщуком [10]. Відбір бджолиного обніжжя для радіологічних досліджень проводили методом точкових проб по 300 грам у кожній партії. Цезій-137 визначали гамма-спектрометричним, стронцій-90 - хімічним способами у Вінницькій філії Інституту родючості грунтів.

Коефіцієнт накопичення цезію-137 у продукції бджільництва бджолиному меді визначали за формулою: $K_{\text {нак. }}=$ Питома акт. цезію- 137 у продукції/питому активність цезію-137 у грунті. Коефіцієнт небезпеки цезію-137 визначали за формулою: $\mathrm{K}_{\text {неб. }}=$ Питома акт. цезію-137 у продукції/ТДР.

Виклад основного матеріалу. Аналіз результатів досліджень (рис. 1) показав, що показник питомої активності цезію-137 у грунтах, на яких вирощували озимий ріпак, складав в середньому 2305 Бк/кг, тоді як на грунтах, на яких вирощували соняшник, даний показник склав 2407 Бк/кг. Тобто, дані грунти на даний час відповідають рівню забруднення зони посиленого радіаційного контролю цезієм-137, межі якого складають 1 - $5 \mathrm{Ki} /$ км $^{2}$.

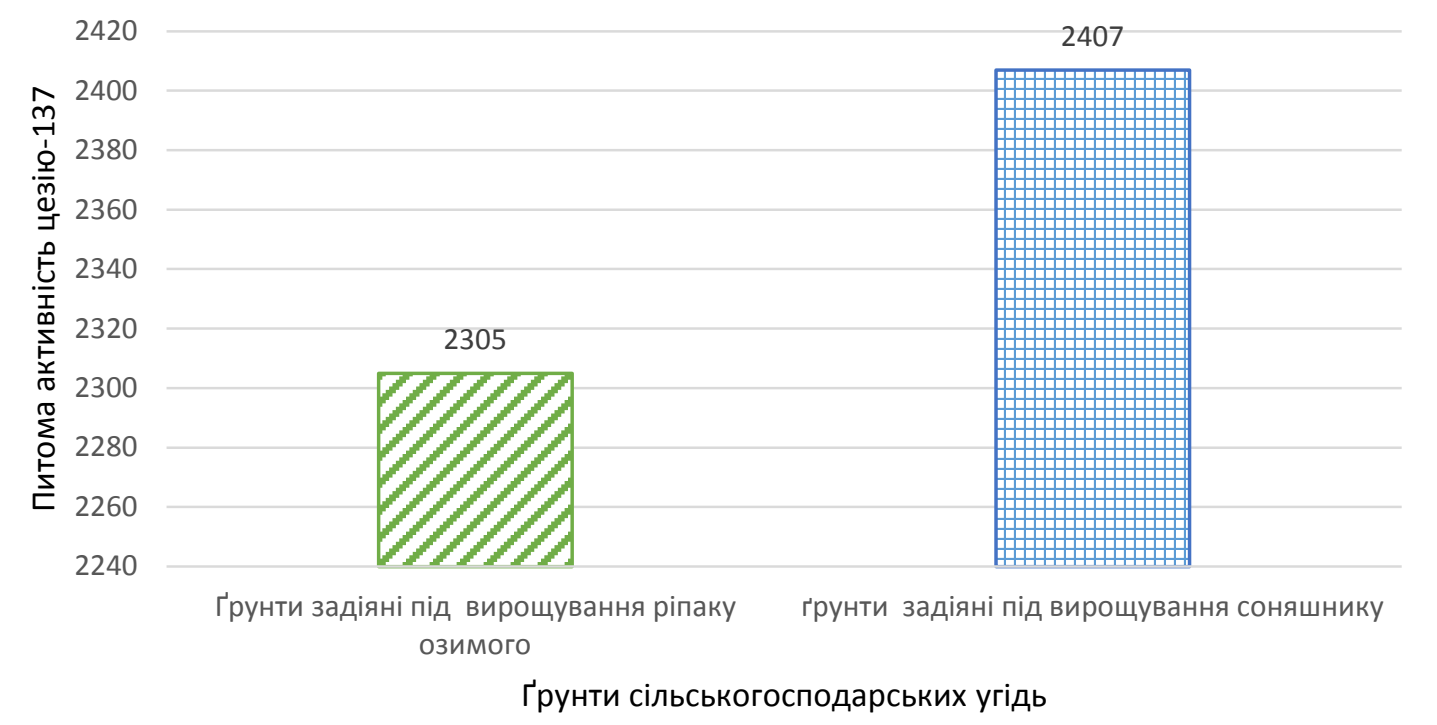

Рис. 1. Інтенсивність забруднення цезісм-137 грунтів, Бк/кг

Джерело: сформовано на основі власних досліджень.

Результати досліджень, відображені в таблиці 2, показують, що питома активність цезію-137 у меді, одержаного з нектару озимого ріпаку за різного мінерального удобрення грунтів не перевищувала допустимі рівні 2006 р. Так, у меді, виробленого бджолами з озимого ріпаку без удобрення грунтів, питома активність цезію-137 була нижча за ДР-2006 у 5,9 раза, за удобрення аміачною селітрою - у 4,5 раза, суперфосфатом простим - у 6,6 раза, калієм хлористим у 8,1 раза та сумішшю (NPK) - у 7,1 раза. Тобто, мінеральне удобрення ріпаку озимого мало певний вплив на питому активність цезію-137 у меді. Водночас необхідно відмітити, що за удобрення грунтів аміачною селітрою, питома активність цезію-137 у меді підвищилась на 26\%. Тоді як за удобрення 
Таблиия 2

Накопичення цезію-137 в меді, виробленого бджолами з нектару озимого ріпаку, Бк/кГ

\begin{tabular}{|c|c|c|c|c|c|}
\hline $\begin{array}{c}\text { Агрохімічні } \\
\text { заходи }\end{array}$ & $\begin{array}{c}\text { Норми } \\
\text { внесення } \\
\text { кг/га }\end{array}$ & ГДК & $\begin{array}{c}\text { Питома } \\
\text { активність } \\
\text { цезію-137 }\end{array}$ & $\begin{array}{c}\text { Коефіцієнт } \\
\text { накопичення }\end{array}$ & $\begin{array}{c}\text { Коефіцієнт } \\
\text { небезпеки }\end{array}$ \\
\hline $\begin{array}{c}\text { Без } \\
\text { удобрення }\end{array}$ & - & 200 & $35,5 \pm 0,31$ & 0,015 & 0,17 \\
\hline $\begin{array}{c}\text { Аміачна } \\
\text { селітра }\end{array}$ & 80 & 200 & $44,5 \pm 0,42$ & 0,019 & 0,22 \\
\hline $\begin{array}{c}\text { Суперфосфат } \\
\text { простий }\end{array}$ & 60 & 200 & $30,2 \pm 0,21$ & 0,013 & 0,15 \\
\hline $\begin{array}{c}\text { Калій- } \\
\text { хлористий }\end{array}$ & 90 & 200 & $24,5 \pm 0,31$ & 0,01 & 0,12 \\
\hline $\begin{array}{c}\text { Суміш } \\
\text { мінеральних } \\
\text { добрив }\end{array}$ & $\mathrm{N}_{80} \mathrm{P}_{60} \mathrm{~K}_{90}$ & $28 \pm 0,2$ & 0,012 & 0,14 \\
\hline
\end{tabular}

Джерело: сформовано на основі власних досліджень

накопичення цезію-137 у суперфосфатом простим, калієм хлористим та сумішшю NPK добрив питома активність цезію-137 в меді знизилась на 14,2\%, $30,4 \%$ та 20\% відповідно.

Характеризуючи коефіцієнти накопичення та небезпеки цезію-137 у меді, виробленого бджолами з нектару озимого ріпаку, необхідно відмітити, що даний показник також змінювався під впливом мінерального удобрення грунтів. Зокрема, за удобрення грунтів аміачною селітрою коефіцієнти накопичення та небезпеки цезію-137 були вищими на 26,6\% і 29,4\% відповідно порівняно 3 варіантом без удобрення. За удобрення грунтів суперфосфатом простим, калієм хлористим та сумішшю NPK добрив коефіцієнти накопичення $\mathrm{i}$ небезпеки цезію-137 у меді, виробленого бджолами з ріпаку озимого, були нижчі відповідно на 13,3\% і 11,7\%, 33,3\% і 29,4\% та 20\% і 17,6\% порівняно 3 варіантом без удобрення. Одержані результати досліджень (табл. 3) щодо

Таблиця 3

Накопичення цезію-137 в бджолиному обніжжі, виробленому бджолами з пилку озимого ріпаку, Бк/кг

\begin{tabular}{|c|c|c|c|c|c|}
\hline $\begin{array}{c}\text { Агрохімічні } \\
\text { заходи }\end{array}$ & $\begin{array}{c}\text { Норми } \\
\text { внесення кг/га }\end{array}$ & ГДК & $\begin{array}{c}\text { Питома } \\
\text { активність } \\
\text { цезію-137 }\end{array}$ & $\begin{array}{c}\text { Коефіцієнт } \\
\text { накопичення }\end{array}$ & $\begin{array}{c}\text { Коефіцієнт } \\
\text { небезпеки }\end{array}$ \\
\hline Без удобрень & - & 200 & $117 \pm 1,2$ & 0,05 & 0,58 \\
\hline Аміачна селітра & 80 & 200 & $145 \pm 1,04$ & 0,06 & 0,72 \\
\hline $\begin{array}{c}\text { Суперфосфат } \\
\text { простий }\end{array}$ & 60 & 200 & $100 \pm 1,27$ & 0,043 & 0,50 \\
\hline Калій хлористий & 90 & 200 & $82 \pm 1,1$ & 0,035 & 0,41 \\
\hline $\begin{array}{c}\text { Суміш } \\
\text { мінеральних } \\
\text { добрив }\end{array}$ & $\mathrm{N}_{80} \mathrm{P}_{60} \mathrm{~K}_{90}$ & 200 & $108 \pm 1,7$ & 0,046 & 0,54 \\
\hline
\end{tabular}

Джерело: сформовано на основі власних досліджень 
бджолиному обніжжі, виробленого бджолами 3 озимого ріпаку за різного удобрення, показали, що концентрація даного радіонукліду не перевищувала ДР-2006. Так, у бджолиному обніжжі, виробленого бджолами 3 пилку озимого ріпаку за удобрення грунтів аміачною селітрою, суперфосфатом простим, калієм хлористим та сумішшю NPK добрив, питома активність цезію-137 була нижча ДР-2006 у 1,3 раза, 2, 2,4 та 1,8 раза відповідно. Певний вплив мінерального удобрення виявлено i на питому активність цезію-137 у бджолиному обніжжі, виробленого бджолами з пилку озимого ріпаку. Зокрема, за удобрення грунтів аміачною селітрою питома активність цезію-137 у бджолиному обніжжі підвищилась на $23,9 \%$, тоді як за використання суперфосату простого, калію хлористого та суміші NPK, навпаки, знизилась на $14,5 \%, 29,9 \%$ та 7,6\% відповідно. Коефіцієнт накопичення цезію-137 у бджолиному обніжжі, виробленого бджолами з озимого ріпаку, підвищився на $20 \%$ за удобрення грунтів аміачною селітрою, а за використання суперфосфату простого, калію хлористого та суміші NPK добрив, навпаки, знизився на 14\%, $30 \%$ та $18 \%$ відповідно порівняно з варіантом без удобрення. Подібна тенденція спостерігалася і по коефіцієнту небезпеки цезію-137 у бджолиному обніжжі. Зокрема, за удобрення грунтів аміачною селітрою спостерігалось підвищення коефіцієнта небезпеки на $24 \%$, тоді як за використання суперфосфату простого, калію хлористого та суміші NPK добрив, навпаки, зниження на 13,8\%, 29,3\% та 6,8\% відповідно порівняно з варіантом без удобрення.

Аналізуючи питому активність цезію-137 у меді, виробленого бджолами 3 нектару соняшнику (табл. 4), необхідно відмітити, що даний показник був

Таблиця 4

Накопичення цезію-137 в меді, виробленого бджолами 3 нектару соняшнику, Бк/кГ

\begin{tabular}{|c|c|c|c|c|c|}
\hline Агрохімічні заходи & $\begin{array}{c}\text { Норми } \\
\text { внесення кг/га }\end{array}$ & ГДК & $\begin{array}{c}\text { Питома } \\
\text { активність } \\
\text { цезію-137 }\end{array}$ & $\begin{array}{c}\text { Коефіцієнт } \\
\text { накопичення }\end{array}$ & $\begin{array}{c}\text { Коефіцієнт } \\
\text { небезпеки }\end{array}$ \\
\hline Без удобрень & - & 200 & $42 \pm 0,31$ & 0,017 & 0,21 \\
\hline Аміачна селітра & 45 & 200 & $57,2 \pm 0,21$ & 0,023 & 0,28 \\
\hline $\begin{array}{c}\text { Суперфосфат } \\
\text { простий }\end{array}$ & 45 & 200 & $38,7 \pm 0,14$ & 0,016 & 0,19 \\
\hline Калій хлористий & 45 & 200 & $28,2 \pm 0,31$ & 0,011 & 0,14 \\
\hline $\begin{array}{c}\text { Суміш мінеральних } \\
\text { добрив }\end{array}$ & $\mathrm{N}_{45} \mathrm{P}_{45} \mathrm{~K}_{45}$ & 200 & $30,7 \pm 0,28$ & 0,012 & 0,15 \\
\hline
\end{tabular}

Джерело: сформовано на основі власних досліджень

нижчий ДР-2006 у варіантах без удобрення у 4,7 раза. За удобрення суперфосфатом простим, калієм хлористим та сумішшю NPK добрив питома активність цезію-137 була нижча за ДР-2006 у 3,5 раза, 5,1 раза, 7,1 раза та 6,5 раза відповідно. За удобрення грунтів аміачною селітрою спостерігалось підвищення питомої активності цезію-137 у бджолиному обніжжі на 35,3\% та коефіцієнту небезпеки на $33,3 \%$ порівняно з варіантом без удобрення. 
Удобрення грунтів суперфосфатом простим, калієм хлористим та сумішшю NPK добрив сприяло зниженню питомої активності цезію-137 на $7,8 \%, 32,8 \%$ та 29,4\%, коефіцієнту накопичення на $14 \%, 30 \%$ i $8 \%$ та коефіцієнту небезпеки на 9,5\%, 33,3\% та 28,5\% відповідно порівняно 3 варіантом без удобрення.

Питома активність цезію-137 у бджолиному обніжжі, виробленого бджолами 3 пилку соняшнику (табл. 5), була нижча порівняно з ДР-2006 у варіантах без удобрення у 1,7 раза, тоді як у варіантах за удобрення аміачною селітрою, суперфосфатом простим та сумішшю МРК добрив дані показники були в межах: у 1,3 раза, 1,9 раза, 2,8 раза та 2,2 раза відповідно. Питома

Таблиия 5

Накопичення цезію-137 в бджолиному обніжжі, виробленого бджолами 3 пилку соняшнику

\begin{tabular}{|c|c|c|c|c|c|}
\hline $\begin{array}{c}\text { Агрохімічні } \\
\text { заходи }\end{array}$ & $\begin{array}{c}\text { Норми } \\
\text { внесення } \\
\text { кг/га }\end{array}$ & ГДК & $\begin{array}{c}\text { Питома } \\
\text { активність } \\
\text { цезію-137 }\end{array}$ & $\begin{array}{c}\text { Коефіцієнт } \\
\text { накопичення }\end{array}$ & $\begin{array}{c}\text { Коефіцієнт } \\
\text { небезпеки }\end{array}$ \\
\hline Без удобрень & - & 200 & $117 \pm 2,3$ & 0,048 & 0,58 \\
\hline Аміачна селітра & 45 & 200 & $151 \pm 1,8$ & 0,062 & 0,75 \\
\hline $\begin{array}{c}\text { Суперфосфат } \\
\text { простий }\end{array}$ & 45 & 200 & $105 \pm 1,1$ & 0,043 & 0,52 \\
\hline Калій хлористий & 45 & 200 & $70,7 \pm 1,3$ & 0,029 & 0,35 \\
\hline $\begin{array}{c}\text { Суміш } \\
\text { мінеральних } \\
\text { добрив }\end{array}$ & $\mathrm{N}_{45} \mathrm{P}_{45} \mathrm{~K}_{45}$ & 200 & $90 \pm 1,4$ & 0,037 & 0,45 \\
\hline
\end{tabular}

Джерело: сформовано на основі власних досліджень

активність та коефіцієнти накопичення і небезпеки цезію-137 у бджолиному обніжжі, виробленого бджолами з пилку соняшнику, були вищі за удобрення грунтів аміачною селітрою на 29\%, 29,1\%, 29,3\% порівняно з варіантом без удобрення. У варіантах за удобрення грунтів суперфосфатом простим, калієм хлористим та сумішшю NPK добрив питома активність цезію-137 у бджолиному обніжжі була нижча на $10,2 \%, 39,5 \%$ та $23 \%$, коефіцієнт накопичення - на $10,4 \%, 39,5 \%, 22,9 \%$ та коефіцієнт небезпеки - на 10,3\%, $39,6 \%$ та 22,4\% відповідно порівняно з варіантом без удобрення. В результаті проведених досліджень також встановлено, що найнижча питома активність цезію-137 у меді і бджолиному обніжжі була виявлена за удобренням грунтів калієм хлористим. Так, питома активність цезію-137 у меді, виробленого бджолами з озимого ріпаку, його коефіцієнти накопичення та небезпеки були нижчі за удобрення грунтів калієм хлористим порівняно з аміачною селітрою на $44,9 \%, 47,3 \%, 45,4 \%$, суперфосфатом простим - на $18,8 \%, 23 \%, 20 \%$ та сумішшю NPK добрив - на $12,5 \%, 16,6 \%, 14,2 \%$ відповідно. У бджолиному обніжжі, виробленого бджолами 3 пилку озимого ріпаку за удобрення грунтів калієм хлористим, питома активність цезію-137 та його коефіцієнти накопичення і небезпеки були нижчі порівняно з аміачною селітрою на 43,4\%, $41,6 \%$ і 43,0\%, суперфосфатом простим - на $18,0 \%, 18,6 \%$ i $18,0 \%$ та сумішшю 
NPK добрив - на 24,0\%, 23,9\% і 24,0\% відповідно. У меді, виробленого бджолами 3 нектару соняшнику за удобрення калієм хлористим, питома активність цезію-137 та його коефіцієнти накопичення і небезпеки були нижчі порівняно 3 аміачною селітрою на $50,6 \%, 2,1$ раза та 2,0 рази, суперфосфатом простим - на 27,1\%, 42\% та 26,3\% і сумішшю NPK добрив - на 7,2\%, 9,0\% та $6,6 \%$ відповідно. У бджолиному обніжжі, виробленого бджолами 3 пилку соняшнику за удобрення грунтів калієм хлористим, питома активність цезію137 та його коефіцієнти накопичення і небезпеки були нижчі порівняно 3 використанням аміачної селітри на $53,1 \%, 53,2 \%$ та 53,3\%, суперфосфату простого - на $32,6 \%, 32,5 \%$ та $32,6 \%$ та суміші NPK добрив - на 67,7\%, 67,5\% та $66,6 \%$ відповідно. Найвищий вплив на накопичення цезію-137 у меді та бджолиному обніжжі, вироблених бджолами з нектару та пилку озимого ріпаку і соняшнику спостерігалась за удобрення грунтів аміачною селітрою. Питома активність цезію-137 у меді, виробленого бджолами з нектару соняшнику за удобрення грунтів аміачною селітрою, була вища на 47,8 \%, у 2 рази та 86,3\% порівняно $з$ суперфосфатом подвійним калієм хлористим та сумішшю NPK добрив. Коефіцієнт накопичення цезію-137 у меді за удобрення грунтів аміачною селітрою був вищим на $43,7 \%$, у 2,1 раза та $91,6 \%$ порівняно 3 використанням суперфосфату подвійного, калію хлористого та суміші NPK добрив. Коефіцієнт небезпеки цезію-137 у меді, виробленого бджолами 3 нектару соняшнику за удобрення грунтів аміачною селітрою, був вищим на $47,3 \%$, у 2 рази та 96,6 \% порівняно з використанням суперфосфату простого, калію хлористого та суміші NPK добрив. Подібна тенденція спостерігалась і по накопиченню цезію-137 у бджолиному обніжжі, виробленого бджолами 3 пилку соняшнику за удобрення грунтів аміачною селітрою. Зокрема, питома активність цезію-137 у бджолиному обніжжі, виготовленого бджолами з пилку соняшнику за удобрення грунтів аміачною селітрою, була вища на 43,8\%, у 2,1 раза та $67,7 \%$, порівняно із суперфосфатом подвійним, калієм хлористим та сумішшю NPK добрив. Характеризуючи коефіцієнти накопичення і небезпеки цезію-137 у бджолиному обніжжі, виробленого бджолами з пилку соняшнику, необхідно відмітити, що дані показники були вищі за удобрення грунтів аміачною селітрою порівняно 3 суперфосфатом простим на 44,1\% і 44,2\%, калієм хлористим - у 2,1 і 2,1 раза та сумішшю NPK добрив - на 67,7\% і 56,6\% відповідно.

Висновки i перспективи подальших досліджень. В результаті проведених досліджень виявлено, що питома активність цезію-137 у меді та бджолиному обніжжі, вироблених бджолами 3 нектару й пилку соняшнику та озимого ріпаку на території, забрудненій даним радіонуклідом, становить від 2305 Бк/кг до 2407 Бк/кг і не перевищує ДР-2006. У меді, виробленого бджолами з нектару ріпаку озимого, у варіанті без удобрення грунтів питома активність цезію-137 була нижча за ДР-2006 у 5,9 раза, тоді як за удобрення аміачною селітрою, суперфосфатом простим, калієм хлористим та сумішшю NPK добрив даний показник склав 4,5 раза, $6,6,8,1$ та 7,0 раза відповідно. У 
бджолиному обніжжі, виробленого бджолами 3 пилку ріпаку озимого, у варіантах без удобрення та за удобрення аміачною селітрою, суперфосфатом простим, калієм хлористим та сумішшю NPK добрив питома активність цезію-137 була нижчою за ДР-2006 у 1,7 раза, 1,3; 2,0; 2,4 та 1,8 раза відповідно. У меді та бджолиному обніжжі, вироблених бджолами 3 нектару і квіткового пилку озимого ріпаку, за удобрення грунтів аміачною селітрою спостерігалось підвищення питомої активності цезію- 137 на 26,0\% і 23,9\%, а за використання суперфосфату простого, калію хлористого та суміші NPK добрив, навпаки, зниження на $14,2 \%$ і $14,5 \%, 30,4 \%$ і $29,9 \%$ та $20 \%$ і $7,6 \%$ відповідно. Найнижча питома активність цезію-137 у меді та бджолиному обніжжі при цьому спостерігалась за удобрення грунтів калієм хлористим, тоді як найвища - при використанні аміачної селітри. У меді та бджолиному обніжжі, вироблених бджолами 3 нектару i квіткового пилку соняшнику, питома активність цезію-137 у варіанті без удобрення була нижча за ДР-2006 у 4,7 раза i 1,7 раза, тоді як за використання аміачної селітри, суперфосфату простого, калію хлористого та суміші NPK добрив даний показник склав 3,5 раза і 1,3 раза, 5,2 раза і 1,9 раза, 7,1 раза і 2,8 раза та 6,5 раза і 2,2 раза відповідно. За використання в якості удобрення грунтів суперфосфату простого, калію хлористого та суміші NPK добрив у меді та бджолиному обніжжі, вироблених бджолами з нектару і квіткового пилку соняшнику, питома активність цезію137 була нижча на 7,8\% і $10,2 \%$, у 32,8 раза і 39,5 раза та $26,9 \%$ і $23 \%$, тоді як за використання аміачної селітри була вища на $36 \%$ і $29 \%$, порівняно 3 варіантом без удобрення. Найнижча питома активність цезію-137 у меді та бджолиному обніжжі, вироблених бджолами з нектару і квіткового пилку соняшнику, була за удобрення грунтів калієм хлористим, а найвища - за використання аміачної селітри.

\section{Список використаної літератури}

1. Алексеніцер М. Л., Бондарчук Л. І., Кубайчук В. П. Забруднення продуктів бджільництва радіонуклідами і вимоги до їх радіометричного контролю. Вісн. агр. науки. 1996. № 4. С. 32-36.

2. Баглей О. В. Оцінка екологічного стану територій за допомогою продуктів бджільництва. Матеріали XII Міжнародної науково-практичної конференції «Проблеми та перспективи розвитку науки на початку третього тисячоліття у країнах СНД»: Збірник наукових прачь. ПереяславХмельницький. 2013. С. 24.

3. Бондарчук Л. І., Мусялковська А. О. Мінеральний склад продуктів бджільництва. Пасіка. 2008. №5. С. 17-19.

4. Васенков Г. І., Кривий М. М., Лісогурська Д. В. Радіоактивне забруднення продукції бджільництва на лісових медозборах Полісся. Вісник Сумського національного аграрного університету. 2018. Вип. 2. С. 132-136.

5. Власенко В. В., Разанов С. Ф. Забруднення меду та бджолиного обніжжя цезієм-137. Пасіка. 1996. № 8. С. 25. 
6. Гудков І.М. Радіобіологія: підручник. Херсон: ОЛДІ-ПЛЮС, 2019. 504 с.

7. Державні гігієнічні нормативи. Допустимі рівні вмісту радіонуклідів ${ }^{137} \mathrm{Cs} \mathrm{i}{ }^{90} \mathrm{Sr}$ у продуктах харчування та питній воді (Наказ MO3 України, 03.05.2006, № 256).

8. Дубін О. М., Василенко О. В. Оцінка якості продукції бджільництва в сучасних екологічних умовах Черкаської області. Вісник Уманського НУС. 2017. № 1. C. 12-17.

9. Калініна І. Г., Долгая М. М. Бджолине обніжжя як маркерний показник екологічного стану довкілля. Біорізноманіття, екологія та експериментальна біологія. 2018. 17. С. 123-128.

10. Ландін В. П. Еколого-економічні засади реабілітації радіоактивно забруднених земель Полісся: монографія. Київ: Аграрна наука, 2018. 208 с.

11. Лісогурська Д. В., Фурман С. В., Кривий М. М. Типи медозбору на Житомирському Поліссі, яке зазнало радіоактивного забруднення. Вісник Сумського національного аграрного університету. 2017. Вип. 5(2). С. 66-70.

12. Поліщук В. П. Бджільництво: Підручник. К.: Вища школа, 2001. 287 с.

13. Разанов С. Ф. Питома активність ${ }^{90} \mathrm{Sr}$ у продукції бджільництва, виробленій на території Полісся. Збірник наукових праџь ВНАУ. 2013. № 2 (72). С 148-158.

14. Разанов С. Ф. Щоб одержати чистий мед. Тваринництвво України. 2007. № 4. С. 40-41.

15. Разанов С. Ф., Недашківський В. М., Разанов О. С. Основи технології виробництва продукції бджільництва: навч. посіб. БНАУ. Вінниця: Нілан, 2018. 195 c.

16. Разанов С. Ф., Шевчук В. В., Коминар М. Ф. Накопичення ${ }^{137} \mathrm{Cs}$ у меді, виробленому бджолами з нектару сільськогосподарських медоносів в умовах північного Полісся. Сільське господарство та лісівницттво. 2020. № 19. С. 148158.

17. Mărgăoan, Rodica et al. Monofloral Honeys as a Potential Source of Natural Antioxidants, Minerals and Medicine. Antioxidants. 2021. 10: n. pag. DOI:10.3390/antiox10071023.

\section{Список використаної літератури у транслітерації / References}

1.Aleksenytser M. L., Bondarchuk L. I., Kubaichuk V. P. (1996). Zabrudnennia produktiv bdzhilnytstva radionuklidamy i vymohy do yikh radiometrychnoho kontroliu [Contamination of beekeeping products with radionuclides and requirements for their radiometric control]. Visn. ahr. nauky. - Visn. agr. science. № 4. 32-36. [in Ukrainian].

2. Bahlei O. V. (2013). Otsinka ekolohichnoho stanu terytorii za dopomohoiu produktiv bdzhilnytstva [Assessment of the ecological condition of the territories with apiculture products]. Materialy XII Mizhnarodnoi naukovo-praktychnoi konferentsii «Problemy ta perspektyvy rozvytku nauky na pochatku tretoho tysiacholittia $u$ krainakh SND»: Zbirnyk naukovykh prats - Collection of scientific works. 
Pereiaslav-Khmelnytskyi. 24. [in Ukrainian].

3. Bondarchuk L. I., Musialkovska A. O. (2008). Mineralnyi sklad produktiv bdzhilnytstva [Mineral composition of beekeeping products]. Pasika. №5. [in Ukrainian].

4. Vasenkov H. I., Kryvyi M. M., Lisohurska D. V. (2018). Radioaktyvne zabrudnennia produktsii bdzhilnytstva na lisovykh medozborakh Polissia [Radioactive contamination of beekeeping products at forest honey harvests in Polissya]. Visnyk Sumskoho natsionalnoho ahrarnoho universytetu - Bulletin of Sumy National Agrarian University. Issue. 2. 132-136. [in Ukrainian].

5. Vlasenko V. V., Razanov S. F. (1996). Zabrudnennia medu ta bdzholynoho obnizhzhia tseziiem-137 [Contamination of honey and bee pollen with cesium-137]. Pasika. № 8. 25. [in Ukrainian].

6. Hudkov I. M. (2019). Radiobiolohiia: pidruchnyk [Radiobiology: a textbook]. Kherson: OLDI-PLIuS. [in Ukrainian].

7. Derzhavni hihiienichni normatyvy. Dopustymi rivni vmistu radionuklidiv ${ }^{137} \mathrm{Cs}$ i ${ }^{90} \mathrm{Sr}$ u produktakh kharchuvannia ta pytnii vodi. (2006). [State hygienic standards. Permissible levels of ${ }^{137} \mathrm{Cs}$ and ${ }^{90} \mathrm{Sr}$ radionuclides in food and drinking water]. (Nakaz MOZ Ukrainy, 03.05.2006, № 256). [in Ukrainian].

8. Dubin O. M., Vasylenko O. V. (2017). Otsinka yakosti produktsii bdzhilnytstva v suchasnykh ekolohichnykh umovakh Cherkaskoi oblasti [Estimation of quality of beekeeping products in modern ecological conditions of Cherkasy region]. Visnyk Umanskoho NUS - Bulletin of Uman NUS. № 1. 12-17. [in Ukrainian].

9. Kalinina I. H., Dolhaia M. M. (2018). Bdzholyne obnizhzhia yak markernyi pokaznyk ekolohichnoho stanu dovkillia [Bee pollination as a marker indicator of the ecological state of the environment]. Bioriznomanittia, ekolohiia ta eksperymentalna biolohiia - Biodiversity, ecology and experimental biology 17. 123-128. [in Ukrainian].

10. Landin V. P. (2018). Ekoloho-ekonomichni zasady reabilitatsii radioaktyvno zabrudnenykh zemel Polissia: monohrafiia [Ecological and economic principles of rehabilitation of radioactively contaminated lands of Polissya: monograph]. Kyiv: Ahrarna nauka. [in Ukrainian].

11. Lisohurska D. V., Furman S. V., Kryvyi M. M. (2017). Typy medozboru na Zhytomyrskomu Polissi, yake zaznalo radioaktyvnoho zabrudnennia. [Types of medical collection in Zhytomyr Polissya, which was exposed to radioactive contamination]. Visnyk Sumskoho natsionalnoho ahrarnoho universytetu - Bulletin of Sumy National Agrarian Universityr. Issue. 5(2). 66-70. [in Ukrainian].

12. Polishchuk V.P. (2001). Bdzhilnytstvo [Apiculture]. [in Ukrainian].

13. Razanov S. F. (2013). Pytoma aktyvnist ${ }^{90} \mathrm{Sr}$ u produktsii bdzhilnytstva, vyroblenii na terytorii Polissia [Specific activity of ${ }^{90} \mathrm{Sr}$ in beekeeping products produced in Polissya]. Zbirnyk naukovykh prats VNAU. - Collection of scientific works of VNAU. № 2 (72). 148-158. [in Ukrainian]. 
14. Razanov S.F. (2007). Shchob oderzhaty chystyi med [To get pure honey]. Tvarynnytstvo Ukrainy - Livestock of Ukraine. № 4. 40-41. [in Ukrainian].

15. Razanov S.F., Nedashkivskyi V.M., Razanov O.S. (2018). Osnovy tekhnolohii vyrobnytstva produktsii bdzhilnytstva: navch. posib [Fundamentals of technology for the production of bee products: textbook. way.]. Bilotserkivskyi natsionalnyi ahrarnyi universytet. Vinnytsia: Nilan. [in Ukrainian].

16. Razanov S.F., Shevchuk V.V., Komynar M.F. (2020). Nakopychennia ${ }^{137}$ Cs $\mathrm{u}$ medi, vyroblenomu bdzholamy $\mathrm{z}$ nektaru silskohospodarskykh medonosiv $\mathrm{v}$ umovakh pivnichnoho Polissia [Accumulation of ${ }^{137} \mathrm{Cs}$ in honey produced by bees from nectar of agricultural honeybees in the conditions of northern Polissya]. Silske hospodarstvo ta lisivnytstvo - Agriculture and forestry. № 19. 148-158. [in Ukrainian].

17. Mărgăoan, Rodica et al. (2021). Monofloral Honeys as a Potential Source of Natural Antioxidants, Minerals and Medicine. Antioxidants. 10: n. pag. DOI:10.3390/antiox10071023. [in Romania].

\section{АННОТАЦИЯ \\ ИНТЕНСИВНОСТЬ НАКОПЛЕНИЯ ЦЕЗИЯ-137 В ПРОДУКЦИИ ПЧЕЛОВОДСТВА ПРИ ВНЕСЕНИИ МИНЕРАЛЬНЫХ УДОБРЕНИЙ В УСЛОВИЯХ РАДИОАКТИВНО ЗАГРЯЗНЕННЫХ ПОЧВ СЕВЕРНОЙ ЧАСТИ ПОЛЕСЬЯ}

Качество и безопасность продукиии растениеводства, в частности, нектара и цветочной пыльцыь, которые являются сырьем производства продукиии пчеловодства, зависит от состояния почвы, ее состава, содержания гумуса, минеральных веществ, уровня увлажнения, а также уровня загрязнения токсикантами.

Особое внимание в последние несколько десятилетий приобретает проблема загрязнения почв различными токсикантами, среди которых высокую опасность представляют радионуклиды, попавщие в окружающую среду в результате аварии на Чернобыльской $А Э С$, которая привела к загрязнению иезием-137 выше 37 кБ/ $\mathrm{m}^{2}$ 461,7 mыс. га сельскохозяйственных угодий, из них пахотных земель - 345,9 тыс. га.

Наибольшие площади угодий, загрязненных иезием-137, находятся в Житомирской (156 тыс. га), Черкасской (76 mысс. га), Ровенской (52 тыс. га), Черниговской (52 тыс. га), Винниикой (50 тыс. га), Киевской (34 mыс. га.) областях. В частности, в Черкасской и Винницкой областях в сельскохозяйственной продукции не выявлено превышения допустимих уровней загрязнения по данному радионуклиду в последние годы.

К территориям, где существует постоянная опасность загрязнения почв и продукиии растениеводства радионуклидами, необходимо отнести прежде всего северные районы Полесья, наиболее пострадавших от аварии на Чернобыльской АЭС.

По результатам проведенных исследований выявлено, что удельная активность цезия -137 в меде и пчелиной обножке, полученных из нектара и иветочной пыльиыы озимого рапса и подсолнечника на почвах с содержанием данного радионуклида от 2305 Бк/кг до 2407 Бк/кг в северной части Житомирщчины, не превымает ДР-2006. В то же время при внесении минеральных удобрений наблюдается повышение удельной активности цезия-137, его коэффициентов опасности и накопления в меде и пчелиной обножке при использовании аммиачной селитры, тогда как при использовании суперфосфата простого, калия хлористого, смеси NPK удобрений данные показатели снижаются. Во всех вариантах, при внесении минеральных удобрений, в меде и пчелиной обножке, производимых пчелами из 
нектара и иветочной пыльи̧ь рапса озимого и подсолнечника, превышений ДР-2006 не наблюдалось. Высшую удельную активность иезия-137, его коэффициентов опасности $и$ накопления в меде и пчелиной обножке, производимых пчелами из нектара и пыльцы из озимого рапса и подсолнечника, было обнаружено в варианте при удобрении почв аммиачной селитрой. Низкое влияние минеральных удобрений на интенсивность транслокации цезия137 в иеепи почва-растение-нектар-мед-цветочная пыльца-пчелиная обножка обнаружено при использовании калия хлористого. При удобрении почвы калием хлористым в меде и пчелиной обножке, производимых пчелами из нектара и пыльиы озимого рапса, удельная активность цезия-137 была ниже, чем при удобрении аммиачной селитрой на 44,9\% и 43,4\%, суперфосфатом простым - на 18,8\% и 18,0\% и смеси NPK удобрений - на $12,8 \%$ u $24,0 \%$.

В меде и пчелиной обножке, производимых пчелами из нектара и пыльцыь подсолнечника, при удобрении почв калием хлористым удельная активность цезия-137 была ниже, чем при использовании аммиачной селитры на 50,6\% и 53,1\%, на 27,1\% и 32,6\% и 7,2\% и $67,7 \%$ соответственно.

Ключевые слова: цезий-137, нектар, цветочная пыльца, мед, пчелиная обножка, удельная активность, озимый рапс, подсолнечник, коэффициент накопления, коэффициент опасности.

Табл. 5. Рис. 1. Лит. 17.

\section{ANOTATION \\ INTENSITY OF CESIUM-137 ACCUMULATION IN PRODUCTS BY HONEY BEES AT THE APPLICATION OF MINERAL FERTILIZERS IN CONDITIONS OF RADIOACTIVELY CONTAMINATED SOILS NORTHERN POLISSYA}

The quality and safety of crop products, in particular nectar and pollen, which are raw materials for the production of beekeeping products, depends on the condition of the soil, its composition, the content of humus, minerals, the level of moisture, as well as the level of pollution with toxicants. Particular attention in the past few decades has been attributed to the problem of soil pollution by various toxicants, among which a high danger is posed by radionuclides that have entered the environment as a result of the accident at the Chernobyl nuclear power plant, which led to the contamination of cesium-137 above $37 \mathrm{kBq} / \mathrm{m}^{2} 461.7$ thousand hectares of agricultural land, of which arable land - 345.9 thousand hectares.

The largest areas of land contaminated with cesium-137 are located in Zhytomyrskaya (156 thousand hectares), Cherkasskaya (76 thousand hectares), Rivnenskaya (52 thousand hectares), Chernigovskaya (52 thousand hectares), Vinnytsia (50 thousand hectares), Kievskaya (34 thousand hectares) regions. In particular, in the Cherkassy and Vinnytsia regions in agricultural products, no excess of the permissible levels of contamination for this radionuclide has been revealed in recent years.

The territories where there is a constant danger of contamination of soil and crop production with radionuclides, it is necessary to include, first of all, the northern regions of Polesie, which were most affected by the accident at the Chernobyl nuclear power plant.

According to the results of the studies, it was revealed that the specific activity of cesium-137 in honey and bee pollen obtained from nectar and pollen of winter rapeseed and sunflower on soils with a content of this radionuclide from $2305 \mathrm{~Bq} / \mathrm{kg}$ to $2407 \mathrm{~Bq} / \mathrm{kg}$ in the northern part of Zhytomyr region is not exceeds DR-2006. At the same time, when applying mineral fertilizers, an increase in the specific activity of cesium-137, its hazard coefficients and accumulation in honey and bee pollen when using ammonium nitrate is observed, while when using simple superphosphate, potassium chloride, a mixture of NPK fertilizers, these indicators decrease. In all variants, with the 
introduction of mineral fertilizers, in honey and bee pollen produced by bees from nectar and pollen of winter rapeseed and sunflower, no excess of DR-2006 was observed.

The highest specific activity of cesium-137, its hazard coefficients and accumulation in honey and bee pollen produced by bees from nectar and pollen from winter rapeseed and sunflower, was found in the variant with soil fertilization with ammonium nitrate. A low effect of mineral fertilizers on the intensity of cesium-137 translocation in the soil - plant - nectar - honey - pollen - bee pollen chain was found when potassium chloride was used. When fertilizing the soil with potassium chloride in honey and bee pollen produced by bees from nectar and pollen of winter rapeseed, the specific activity of cesium-137 was lower than when fertilized with ammonium nitrate by $44.9 \%$ and $43.4 \%$, simple superphosphate - by $18,8 \%$ and $18.0 \%$ and a mixture of NPK fertilizers - by $12.8 \%$ and $24.0 \%$. In honey and bee pollen produced by bees from sunflower when fertilizing soils with potassium chloride, the specific activity of cesium-137 was lower than when using ammonium nitrate by $50.6 \%$ and $53.1 \%$, by $27.1 \%$ and $32.6 \%$, and $7.2 \%$ and $67.7 \%$, respectively.

Key words: cesium-137, nectar, pollen, honey, bee pollen, winter rapeseed, sunflower, accumulation coefficient, hazard coefficient.

Table. 5. Fig. 1. Lit. 17.

\section{Інформація про авторів}

Разанов Сергій Федорович - доктор сільськогосподарських наук, професор кафедри екології та охорони навколишнього середовища факультету агрономії та лісівництва Вінницького національного аграрного університету (21008, м.Вінниця, вул.Сонячна, 3; e-mail: razanov@vsau.vin.ua).

Коминар Микола Федорович - аспірант Інституту агроекології i природокористування НААН (03143, м.Київ, вул. Метрологічна, 12; e-mail: nik190778@ukr.net).

Разанов Сергей Федорович - доктор сельскохозяйственных наук, профессор кафедры экологии и охраны окружающей среды факультета агрономии и лесоводства Винницкого национального аграрного университета (21008, г. Винница, ул.Солнечная, 3; e-mail: razanov@vsau.vin.ua ).

Комынар Николай Федорович - аспирант Института агроэкологии и природопользования НАAН (03143, г. Киев, ул. Метрологическая, 12; e-mail: nik190778@ukr.net).

Razanov Sergey - Doctor of Agricultural Sciences, Professor of the Department of Ecology and Environmental Protection, Faculty of Agronomy and Forestry, Vinnytsia National Agrarian University (21008, Vinnytsia, Soniachna str.3; e-mail: razanov@vsau.vin.ua).

Komynar Mykola - Postgraduate student of the Institute of Agroecology and Nature Management of the NAAS (03143 , Kiev, Metrologicheskaya str., 12; e-mail: nik190778@ukr.net). 